\title{
Detection of Toxoplasma gondii DNA in peripheral blood and aqueous humor of patients with Toxoplasmic active focal necrotizing retinochoroiditis using real-time PCR
}

\author{
Detecção de DNA do Toxoplasma gondii no sangue periférico e humor aquoso por PCR em tempo real \\ Fabio Felipe dos Santos ${ }^{1}$, Heloisa Nascimento ${ }^{1}$, Cristina Muccioli¹, Deise Fialho da Costa ${ }^{1}$, Luiz Vicente Rizzo², Alessandra Gonçalves Commodaro ${ }^{1}$, \\ RUBEens BELFORT JR. ${ }^{1}$
}

\begin{abstract}
Purpose: To evaluate the ability of real-time quantitative PCR ( $(P C R$ ) for detecting Toxoplasma gondii DNA in the peripheral blood and aqueous humor of patients with toxoplasmic active focal necrotizing retinochoroiditis.

Methods: Fifty-five patients with infectious uveitis seen from 2009 to 2013 at the Department of Ophthalmology and Visual Sciences of the Federal University of São Paulo were enrolled in this study. Forty-three patients had toxoplasmic active focal necrotizing retinochoroiditis, and the remaining 12 had non-toxoplasmic infectious uveitis and served as controls. QPCR analysis for T. gondii DNA was performed on the patients' peripheral blood and aqueous humor samples.

Results: The qPCR was positive for T. gondii DNA in $37.21 \%(16 / 43)$ of the aqueous humor samples and $2.33 \%$ (1/43) of the peripheral blood samples; further, $16.27 \%$ $(7 / 43)$ of the patients had positive results in both their blood and aqueous humor samples.

Conclusion: GPCR was able to detect T. gondii DNA in patients with toxoplasmic active focal necrotizing retinochoroiditis in the blood as well as the aqueous humor and can help with the diagnosis of the disease.
\end{abstract}

Keywords: Toxoplasmosis, ocular/diagnosis; Toxoplasma;Blood/parasitology; Choroiditis; Real-time polymerase techniques/methods; Aqueous humor

\section{RESUMO}

Objetivo: Analisar o uso do PCR em tempo real ( $(P C R)$ na detecção do DNA do T. gondii no sangue periférico e no humor aquoso de pacientes com lesões de retinocoroidite focal, ativa por toxoplasmose.

Métodos: Cinquenta e cinco pacientes com uveite infecciosa foram incluídos neste estudo. Os pacientes foram atendidos entre 2009 a 2013, no Departamento de Oftalmologia e Ciências Visuais da Universidade Federal de São Paulo. Quarentae três pacientes tiveram o diagnóstico de lesões de retinocoroidite focal, ativa por toxoplasmose e, os outros 12 tiveram o diagnóstico de uveíte infecciosa não toxoplásmicae, por isso foram usados como grupo controle. A técnica de aPCR foi utilizada na detecção de DNA do T. gondii em amostras de sangue periférico e humor aquoso.

Resultados: O qPCR foi positivo para o DNA do T. gondii em 37,21\% (16/43) das amostras de humor aquoso, 2,33\% (1/43) nas amostras de sangue periférico e, 16,27\% (7/43) em ambas amostras simultaneamente.

Conclusão: $O$ aPCRfoicapaz de detectar o DNA do T. gondii em pacientes com lesões de retinocoroidite focal, ativa por Toxoplasmose, no sangue bem como, no humor aquoso, podendo ajudar no diagnostico.

Descritores: Toxoplasmose ocular/diagnóstico; Toxoplasma; Sangue/parasitologia; Coriodite; Reação em cadeia da polimerase em tempo real; Humor aquoso

\section{INTRODUCTION}

Toxoplasma gondii infection is the most common cause of posterior uveitis worldwide and is an important cause of ocular disease in both immunocompromised and immunocompetent individuals ${ }^{(1)}$, accounting for $30 \%$ to $50 \%$ of uveitis in different countries ${ }^{(2)}$.

The prevalence of T. gondii infection in adults in Brazil ranges from $50 \%$ to $80 \%$ depending on the region studied ${ }^{(1,3-5)}$. In Erechim, a city located in the south of Brazil, $88 \%$ of the population is seropositive for T. gondii, with $18 \%$ developing ocular toxoplasmosis ${ }^{(5,6)}$.

Clinical diagnosis of ocular toxoplasmosis is usually made by ophthalmic examination. Molecular biology techniques can be successfully used to detect T. gondii DNA ${ }^{(7)}$ when the clinical diagnosis is unclear. Polymerase chain reaction (PCR) can detect microorganism DNA and is a rapid method with high sensitivity and specificity that has been used to detect T. gondii DNA in different biological samples ${ }^{(8,9)}$. With the recent advances in molecular biology, the use of real-time PCR makes quantitative measurement of T. gondii DNA possible in patients with ocular toxoplasmosis ${ }^{(10-12)}$. Rapid recogni- tion of specific infections is important for adequate management of uveitis ${ }^{(13)}$.

The aim of this study was to evaluate the ability of real-time quantitative PCR (qPCR) for the detection of T. gondii DNA in peripheral blood and aqueous humor samples of patients with toxoplasmic active focal necrotizing retinochoroiditis.

\section{METHODS}

\section{Patients}

Fifty-five patients with uveitis seen from 2009 to 2013 at the Department of Ophthalmology and Visual Sciences of the Federal University of São Paulo were included in this study. From the 55 patients, 43 were diagnosed with toxoplasmic active focal necrotizing retinochoroiditis. The remaining 12 were diagnosed with non-toxoplasmic infectious uveitis (toxocariasis=6, tuberculosis=3, and herpes virus=3), and served as controls.

${ }^{2}$ Hospital Albert Einstein, São Paulo, SP, Brazil.

Funding: This work was supported by grants from FAPESP, CNPq-473179/2011-3, instituto da visão and CAPES.

Disclosure of potential conflicts of interest: None of the authors have any potential conflict of interest to disclose.

Corresponding author: Alessandra G. Commodaro. Rua Botucatu, 822 - São Paulo, SP - 04023-062 Brasil - E-mail: alecommodaro@gmail.com 
The study was approved by the local ethics committee investigational review board (0094/09), and informed consent was obtained from all patients.

\section{SAMPLes}

The samples were collected by an ophthalmologist. Peripheral blood ( $5 \mathrm{ml}$ ) was collected in EDTA tubes. Approximately $0.1 \mathrm{ml}$ of the aqueous humor was collected by anterior chamber paracentesis with a 30-gauge needle. Aqueous samples were obtained from patients who had at least two anterior chamber cells.

A total of 43 peripheral blood and 43 aqueous humor samples were collected from 43 patients with toxoplasmic necrotizing active focal retinochoroiditis and two or more inflammatory cells in the aqueous humor. Twelve non-toxoplasmic patients with active uveitis and two or more inflammatory cells in the aqueous humor (12 peripheral blood and 12 aqueous humor samples) were used as controls.

\section{DNA EXTRACTION}

Total DNA was extracted from the peripheral blood and aqueous humor with a commercially available DNA mini column kit (Qiagen, Hilden, Germany) according to the manufacturer's protocol. The DNA samples were stored at $-20^{\circ} \mathrm{C}$ until use.

\section{REAL-TIME QPCR}

Real-time qPCR was performed using TaqMan $10 \mu$, with sense and antisense primers at a concentration of $10 \mathrm{mM}, 0.4 \mu$ l of probe $6.8 \mu \mathrm{l}$ of nuclease- and DEPC-free water (Invitrogen, Carlsbad, CA, USA), and $2 \mu$ of DNA, with a total reaction volume of $20 \mu \mathrm{l}$. qPCR was performed on an ABI Prism 7500 DNA sequence detection system (Applied Biosystems, Waltham, MA, USA) and targeted the T. gondii 529-bp repetitive genomic sequence (rep529) ${ }^{(14,15)}$ and the B1 gene ${ }^{(16)}$. $\beta$-globin QPCR was performed in parallel for each sample as described previously ${ }^{(17)}$ in order to confirm the integrity of the DNA and to verify the PCR inhibitors.

\section{RESULTS}

Real-time qPCR analysis detected T. gondii DNA in 37.21\% (16/43) of the aqueous humor samples and $2.33 \%$ (1/43) of the peripheral blood samples; further, $16.27 \%$ (7/43) of the patients had positive results in both the peripheral blood and aqueous humor samples (Table 1).

Further, among the 43 patients, the gPCR analysis showed negative results in both the peripheral blood and aqueous humor samples in 19 patients (data not shown).

In the control group $(n=12)$, all samples analyzed showed negative qPCR results for T. gondii (data not shown).

\section{DISCUSSION}

Blindness and visual impairment caused by infectious uveitis can be prevented at least partially by early identification of the pathogen and the subsequent administration of appropriate treatment ${ }^{(18)}$. The

Table 1. Real-time quantitative polymerase chain reaction (qPCR) positivity of Toxoplasma gondii DNA in the peripheral blood and aqueous humor samples of patients with toxoplasmic active focal necrotizing retinochoroiditis.

\begin{tabular}{lccc}
\hline & \multicolumn{3}{c}{ Real-time PCR } \\
\cline { 2 - 4 } & $\begin{array}{c}\text { Peripheral } \\
\text { blood }\end{array}$ & $\begin{array}{c}\text { Aqueous } \\
\text { humor }\end{array}$ & $\begin{array}{c}\text { Both peripheral blood } \\
\text { and aqueous humor }\end{array}$ \\
\hline № of positive/total & $1 / 43$ & $16 / 43$ & $7 / 43$ \\
$\%$ & 2.33 & 37.21 & 16.27 \\
\hline
\end{tabular}

use of real-time PCR as a diagnostic tool for infectious uveitis has been demonstrated by many groups ${ }^{(11,19-21)}$

In this study, qPCR identified T. gondii infection in $37.21 \%$ of the aqueous humor samples, confirming the clinical hypothesis of toxoplasmic active focal necrotizing retinochoroiditis. A previous study reported that aqueous PCR analyses are useful in AIDS patients with ocular toxoplasmosis (sensitivity of 75\%)(19) and demonstrated that the aqueous humor is the best source for identifying T. gondii infection. Another study also detected T. gondii DNA (38\%) by PCR in aqueous humor samples ${ }^{(16)}$.

PCR has been found to detect T. gondii DNA more effectively in aqueous humor (25\%) than in peripheral blood (5\%) samples ${ }^{(22)}$. Recently, a study demonstrated that the sensitivity for blood was poor (4.1\%) compared with that for ocular samples (35.9\%) ${ }^{(23)}$. These findings corroborate our results, which showed that the ability of PCR to detect T. gondii DNA was more sensitive in aqueous humor (37.21\%) than in peripheral blood samples (2.33\%). Positive results in the peripheral blood were found in only one patient (2.3\%), while positive results were found in both peripheral blood and aqueous humor samples in $16.27 \%$ of the patients. This finding confirms that qPCR can identify parasites circulating in the peripheral blood of patients. T. gondii has been found in the blood of acutely and chronically infected patients with ocular toxoplasmosis ${ }^{(24)}$.

\section{CONCLUSION}

qPCR is a useful tool for detecting T. gondii DNA in patients with toxoplasmic active focal necrotizing retinochoroiditis and may help in the establishment of appropriate treatment, with the exception of noninfectious uveitis or infectious uveitis caused by other pathogens.

\section{REFERENCES}

1. Cordeiro CA, Moreira PR, Dutra WO, Young L, Campos WR, Oréfice F, et al. Imunologia da retinocoroidite toxoplásmica. Arq Bras Oftalmol. 2010;73(6):548-51. Comment in: Arq Bras Oftalmol. 2011;74(3):227.

2. de-la-Torre A, Sauer A, Pfaff AW, Bourcier T, Brunet J, Speeg-Schatz C, et al. Severe South American ocular toxoplasmosis is associated with decreased Ifn- $\gamma / 1-17 \mathrm{a}$ and increased II-6/II-13 intraocular levels. PLoS Negl Trop Dis. 2013;7(11):e2541.

3. Garcia JL, Navarro IT, Ogawa L, de Oliveira RC, de Faria Garcia SM, Leite J. Soroepidemiologia da toxoplasmose e avaliação ocular pela Tela de Amsler, em pacientes da zona rural, atendidos na unidade de saúde do município de Jaguapitã, PR, Brasil. Rev Soc Bras de Med Trop. 1999;32(6):671-6.

4. Kompalic-Cristo A, Britto C, Fernandes O. Diagnóstico molecular da toxoplasmose: revisão. J Bras Patol Med Lab. 2005;41(4):229-35.

5. Khan A, Jordan C, Muccioli C, Vallochi AL, Rizzo LV, Belfort Jr R, et al. Genetic divergence of Toxoplasma gondii strains associated with ocular toxoplasmosis. Brazil. Emerg Infect Dis. 2006;12(6):942-9.

6. Silveira C, Belfort Jr R, Muccioli C, Abreu MT, Martins MC, Victoria C, et al. A Follow-up study of Toxoplasma gondii infection in Southern Brazil. Am J Ophthalmol. 2001; 131(3):351-4.

7. Park YH, Nam HW. Clinical features and treatment of ocular toxoplasmosis. Korean J Parasitol. 2013;51(4):393-9.

8. Cantos GA, Prando MD, Siqueira MV, Teixeira RM. Toxoplasmose: ocorrência de anticorpos antitoxoplasma gondii e diagnóstico. Rev Assoc Med Bras. 2000;46(4):335-41.

9. Bou G, Figueroa MS, Martí-Belda P, Navas E, Guerrero A. Value of PCR for detection of toxoplasma gondii in aqueous humor and blood samples from immunocompetent patients with ocular toxoplasmosis. J Clin Microbiol. 1999;37(11):3465-8.

10. Costa JG, Carneiro AC, Tavares AT, Andrade GM, Vasconcelos-Santos DV, Januário JN, et al. Real-time PCR as a prognostic tool for human congenital toxoplasmosis. J Clin Microbiol. 2013;51(8):2766-8.

11. Santos FF, Commodaro AG, Souza AV, Pinho JR, Sitnik R, Garcia C, et al. Real-time PCR in infectious uveitis as an alternative diagnosis. Arq Bras Oftalmol. 2011;74(4):258-61.

12. Novais EA, Commodaro AG, Santos F, Muccioli C, Maia A, Nascimento H, et al. Patients with diffuse uveitis and inactive toxoplasmic retinitis lesions test PCR positive for Toxoplasma gondii in their vitreous and blood. Br J Ophthalmol. 2014;98(7):937-40.

13. Aouizerate F, Cazenave J, Poirier L, Verin P, Cheyrou A, Begueret J, et al. Detection of Toxoplasma gondii in aqueous humour by the polymerase chain reaction. $\mathrm{Br} J$ Ophthalmol. 1993;77(2):107- 9.

14. Danise A, Cinque P, Vergani S, Candino M, Racca S, De Bona A, et al. Use of polymerase chain reaction assays of aqueous humor in the differential diagnosis of retinitis in patients infected with human immunodeficiency vírus. Clin Infec Dis. 1997;24(6):1100-6. 
15. Hierl T, Reischl U, Lang P, Hebart H, Stark M, Kyme P, et al. Preliminary evaluation of one conventional nested and two real time PCR assays for the detection of Toxoplasma gondii in immunocompromised patients. J Med Microbiol. 2004;53(Pt 7):629-32.

16. Fekkar A, Bodaghi B, Touafek F, Le Hoang P, Mazier D, Paris L. Comparison of immunoblotting, calculation of the goldmann-witmer coefficient, and real-time PCR using aqueous humor samples for diagnosis of ocular toxoplasmosis. J Clin Microbiol. 2008; 46(6):1965-7.

17. Bispo PJ, de Melo GB, Hofling-Lima AL, Pignatari AC. Detection and gram discrimination of bacterial pathogens from aqueous and vitreous humor using real-time PCR assays. Invest Ophthalmol Vis Sci. 2011:52(2):873-81.

18. London NJ, Rathinam SR, Cunningham ET Jr. The epidemiology of uveitis in developing countries. Int Clin Ophthalmol. 2010;50(2):1-17.

19. Matos K, Muccioli C, Belfort Jr. R, Rizzo LV. Correlation between clinical diagnosis and PCR analysis of serum, aqueous, and vitreous samples in patients with inflammatory eye disease. Arq Bras Oftalmol. 2007;70(1):109-14.
20. Oahalou A, Schellekens PA, de Groot-Mijnes JD, Rothova A. Diagnostic pars plana vitrectomy and aqueous analyses in patients with uveitis of unknown cause. Retina. 2014;34(1):108-14

21. Sugita S, Ogawa M, Shimizu N, Morio T, Ohguro N, Nakai K, et al. Use of a comprehensive polymerase chain reaction system for diagnosis of ocular infectious diseases. Ophthalmology. 2013;120(9):1761-8.

22. Lee SE, Hong SH, Lee SH, Jeong YI, Lim SJ, Kwon OW, et al. Detection of ocular Toxoplasma gondii infection in chronic irregular recurrent uveitis by PCR. Korean J Parasitol. 2012;50(3):229-31.

23. Bourdin C, Busse A, Kouamou E, Touafek F, Bodaghi B, Le Hoang P, et al. PCR-based detection of Toxoplasma gondii DNA in blood and ocular samples for diagnosis of ocular toxoplasmosis. J Clin Microbiol. 2014;52(11):3987-91.

24. Silveira C, Vallochi AL, Rodrigues da Silva L, Muccioli C, Holland GN, Nussenblatt RB, et al. Toxoplasma gondii in the peripheral blood of patients with acute and chronic toxoplasmosis. Br J Opththalmol. 2011;95(3):396-400.

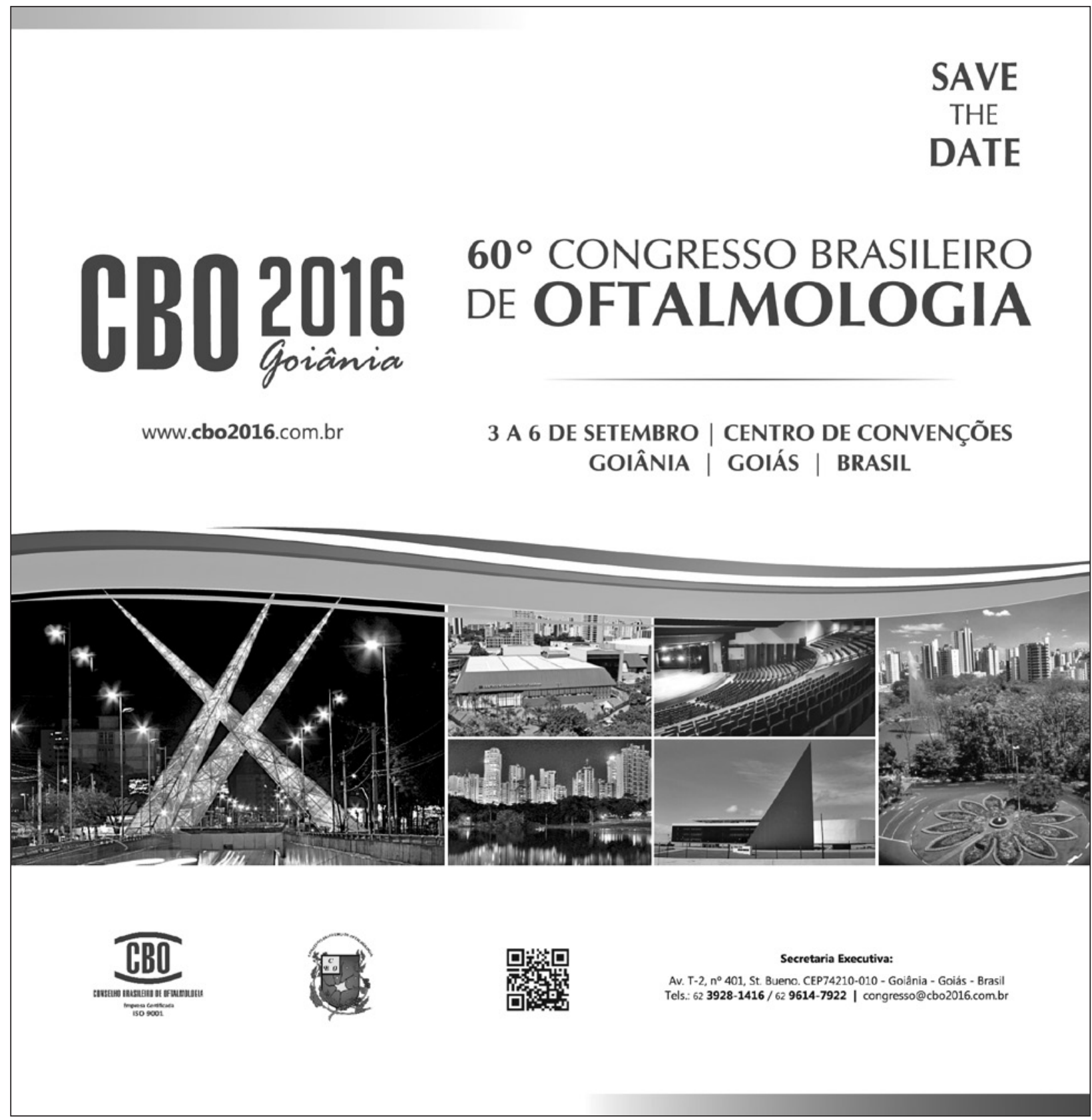

